\title{
Regime Network Restructuring in Akron, Ohio, 1975-2009: A Longitudinal Social Network Analysis
}

\author{
MARK DE SOCIO
}

\begin{abstract}
The purpose of this paper is to explore the impacts of extra-local economic and political forces on the business community participants of the governing regime coalition in Akron, Ohio, and in turn, how other regime partners responded to and engaged with the changing constitution of Akron's business community. Unlike the UK where municipalities receive substantial fiscal support from regional and national governments, American cities are more readily forced into regime partnerships with other public and private actors for fiscal solvency, including, primarily, the local business community. In the case of Akron, the local business community experienced a prolonged and ongoing period of comprehensive deindustrialization and economic restructuring, forcing the city into partnerships with less traditional non-private sector actors as Akron's business community structure continues to transform. A secondary objective is to forward the utility of social network analysis in regime theory applications. Social network analysis offers a way to situate arguably the most influential actors in a regime coalition. Utilizing the directories of Standard and Poor's Index of Corporations and Directors from 1975 through 2006, social network analysis is performed on the interlocking network of corporations and civic organizations based in Akron for each decade, allowing a longitudinal view of the changing business community partners of Akron's governing coalition.
\end{abstract}

\begin{abstract}
fter more than two decades of prominence, urban regime theory remains at 1 the forefront in analyses of urban politics and urban political restructuring due in large part to its grounding in political economy, its ability to convey the complexities of urban politics, and its continuing emphases on coalition building and maintenance including examinations of the various constituent parts comprising urban coalitions (de Socio 2007; Hackworth 2007; Hanson et al. 2010; Imbroscio 2003, 2010; Smith 2010; Tretter 2008; Wood 2004). Regime theory is not without its detractors, however. Indeed, one salient critique leveled against regime theory is its particularly localist orientation. The general argument is that regime

Mark de Socio is an associate professor of Geography and Geosciences at the Department of Geography and Geosciences, Salisbury University, Salisbury, Maryland, USA. His e-mail address is: mxdesocio@salisbury.edu. The author extends many thanks to the editor and anonymous referees for their excellent comments and suggestions.
\end{abstract}

Submitted December 2010; revised April 2011; accepted May 2011.

(C) 2012 Wiley Periodicals, Inc 
theorists over emphasize local actors - whether members of the local business community, or the role of local institutions like mayoral administrations or civic and policy organizations - and their contributions to a regime's capacity to govern (Hackworth 2007; Lauria 1997; Tretter 2008; Ward 1996). By doing so, the role of extra-local actors and processes - whether governments of wider jurisdictions like U.S. states (Burns and Thomas 2004; Smith 2010) or British regional governing units (Cox 2004; Tretter 2008), or wider economic and political forces like global economic restructuring (Fainstein et al. 1986; Harvey 1989; Wood 2005), devolution (Hackworth 2007; Wood 2004), supranationalism (Tretter 2008), or the broad ideological project of neoliberalism (Hackworth 2007; Harvey 2005; Ward 1996) - are largely overlooked or simply missing from most accounts of regime formation and operation. Indeed, regime theory's main emphases on local regime formation with locally based partners driving the process with the aim of affecting the scope, shape, and direction of inward capital flows is seen as geographically myopic and privileging —indeed, "fetishizing"- the local scale (Brenner 2009).

Another, related, critique is aimed at regime theory's most central component: the division of labor between market and state, at least as it is formulated by Stone (1989, 1993) (Cox 1997; Imbroscio 2010). Imbroscio (2010) forcefully argues that Stone's interpretation of the division between state and market is too rigid and that his understandings of capital accumulation in the urban setting is too limiting. In Stone's reading, capital accumulation solely rests in the private sector as defined in neoclassical terms. The role or potential of the state and nonprofit sectors in capital accumulation like publicly owned enterprises or communitybased development corporations are given short shrift by Stone and most other regime theorists (Imbroscio 2010). Cox (1997), meanwhile, finds that the regime model under-theorizes the division between the public and private sectors which undergirds the need for cooperation and coordination across sectors. Regime theory conceptualizes local governments (particularly in the U.S.) as rather limited in their abilities to exercise public authority vis-à-vis governments at the regional, state, and national levels and suggests that they therefore must enter into partnerships with other actors who command the kinds of resources necessary for effective governance (Stone 1989). For example, business leaders are seen as essential to most if not all regime coalitions due to the significant resources at their command, namely jobs and capital, and which cities require for fiscal solvency (Imbroscio 1998; Stone 1989). However, Cox maintains that apart from various references to major stakes in Atlanta's downtown in the form of property ownership, Stone's seminal account of regime theory does not adequately theorize why private sector actors (or, indeed, other actors more generally) would, a priori, necessarily partner with local governments. 
Following Jonas (1992) and Cox and Mair (1988), this paper takes the view that a range of locally based actors-local governments, people, civic organizations, and capitalist firms operating at a range of scales, from local to global-are in some measure immobile and, in varying degrees, locally dependent on the reproduction of particular social relations at the metropolitan scale. It is this immobility and local dependence that compels local actors into partnerships with other agents (local or otherwise), including the local state, in order to affect the reproduction of social relations in ways that are beneficial, or in the least not detrimental, to their own practices of capital accumulation. Indeed, this is the essence of regime theory-a two-way or multidirectional partnership even though regime theorists have traditionally focused on one particular direction: that of the local state and its structural limitations that force it to seek partnerships with other actors who command the mix and scope of resources that lend localities their capacity to govern.

Tretter's (2008) case study of Glasgow's development of a regime coalition around the European City of Culture theme illustrates how, for example, regime formation can be multidirectional and multi-scalar. In seeking to build an effective coalition with the aim of (re)developing Glasgow's deteriorating urban core and to "re-image" the city to attract inward capital flows, local government officials and business community representatives found ready partners at the levels of regional and national government and at the level of the European Union, each of whom were eager to latch on to the recognition of Glasgow as a European City of Culture in the furtherance of their own particular political aims. Tretter compellingly unpacks how nonlocal factors like the external opportunity posed by the European Union and its European City of Culture project provided the "identifying agenda" (Stone 2001) around which to organize. Additionally, the City of Culture project pulled in multi-scalar actors that, in turn, played a significant role in shaping the particular direction of Glasgow's redevelopment efforts.

Apart from Tretter's focus on extra-local actors and how they managed to put their own particular and multi-scalar stamp on Glasgow's regime politics, the basic structural problem of fiscal and legal constraints for municipalities remains as does the problem of local dependency among a range of local actors, including capitalist firms. (Indeed, always present in Tretter's account were local actors including representatives of Glasgow's business community). The growth machine model, for example, demonstrates the dependency of various actors-local governments, universities, media firms, property owners, and the like — on a particular social order that promotes population growth and economic development in order to generate increased tax revenues, college enrollments, media subscriptions, property exchange values, and so on (Logan and Molotch 1987). Jonas (1992) and Cox and Mair (1988), meanwhile, illustrate that capitalist firms, including 
multinationals, are likewise embedded in particular (often multiple) places via a range of place-based commitments like the siting of corporate headquarters and production facilities, but also through socially produced supplier networks, specialized labor forces, and various other forward and backward linkages that are generally quite difficult and very costly to uproot from a particular location and are not easily reproduced elsewhere. Indeed, in his case study of the Norton Company in Worcester, Massachusetts, Jonas illustrates how local supplier and labor relations were developed and nurtured over time and with much commitment of social and political capital through charitable giving and civic engagement in order to gain and maintain the loyalty of its workforce on the one hand, and to successfully undermine various attempts at union organization on the other.

While locally dependent firms often engage in partnerships with localities in order to enforce the reproduction of social relations that, in turn, facilitate private capital accumulation, they nevertheless are shaped and defined by broader extralocal forces like globalization, technological change, and the dynamism of capitalist competition in general as illustrated by Jonas. The nearly always-present business communities in regime coalitions, then, are subject to constant and intensive competition across scales. Consequently, regime coalitions face continuous, often dramatic change as the resources at the command of business community partners are often in a state of flux, increasing and decreasing in quantity and quality, and perhaps changing in type and function, as the economic sectors to which they belong are themselves transformed by global economic forces (de Socio 2007; DiGaetano and Klemanski 1989).

The purpose of this paper is two-fold. The primary objective is to explore, via a longitudinal case study of Akron, Ohio, the impacts of extra-local economic and political forces on the business community participants of Akron's governing regime coalition and, in turn, how other regime partners responded to and engaged with the changing constitution of Akron's business community. Unlike the UK, where municipalities receive substantial fiscal support from regional and national government, American cities are more readily forced into regime partnerships with other (typically local or regional-based) public and private actors for fiscal solvency (Cox 1997; Wood 2005). In the case of Akron, the local business community experienced a prolonged and ongoing period of comprehensive deindustrialization and economic restructuring, forcing the municipality into partnerships with less traditional, non-private sector, actors (namely nonprofit universities and hospitals) as Akron's business community structure continues to transform. A secondary objective is methodological; that is, to forward the utility of social network analysis in regime theory applications. By conceptualizing urban regimes as multi-scalar networks of firms, policy organizations, and civic 
institutions, we can examine how locally dependent interests articulate with those of wider geographical extent (Tretter 2008; Wood 2005). Social network analysis offers a way to situate arguably the most influential actors in a regime network, whether business or other community leaders (de Socio 2010). Utilizing the directories of Standard and Poor's Index of Corporations and Directors from 1975 through 2006, social network analysis is performed on the interlocking network of corporations based in Akron for each decade, allowing a longitudinal view of Akron's changing business community leadership - that is, the changing business community partners of Akron's governing coalition.

The remainder of the paper is structured as follows. The following section reviews Akron's changing economic base and the challenges it posed and continues to pose to Akron's municipal government. Literature on urban regime theory is then presented with a view toward conceptualizing regimes as resource-rich social networks of interconnected corporations, civic institutions, and business policy organizations linked by interlocking directorates, followed by a brief review of social network analysis. Social network analyses of Akron's interlocked corporations from 1975 through 2006 is performed, followed by a fuller exploration of Akron's current regime and its agenda for restructuring Akron's base economy and urban land use. Finally, wider implications of Akron's policy agenda, along with future research possibilities, are considered in the conclusion.

\section{Business Community (Re)structuring in Akron, Ohio}

When Donald Plusquellic was elected Mayor of Akron, Ohio in 1986, the city was in the midst of severe economic decline. For more than a hundred years, Akron - widely known as the "Rubber City"-was home to several of the world's largest tire manufacturers (for example, BF Goodrich, Goodyear, Firestone, and General Tire) and their suppliers. In 1960, the city's rubber employment stood at nearly 33,000 jobs, and the city's overall population had reached a peak of more than 300,000 (Love and Giffels 1999). The oil shocks of 1973, however, had a devastating impact on Akron and its tire manufacturers. Rapid shifts in demand for more fuel-efficient automobiles among American consumers opened the U.S. auto market to European and Japanese car manufacturers, whose cars were mostly fitted with radial tires produced in Japan and Europe (Love and Giffels 1999). Radial tires incorporated a rubber-coated steel belt into its design that doubled the life of tires and created less drag, thus proving to be more fuel efficient than the standard bias tire found in the U.S. (Love and Giffels 1999). Because radial tires required a high degree of precision in manufacturing, the costs of retooling and upgrading existing production facilities gave pause to U.S. tire makers. Further, U.S. automakers were reluctant to shift to radial tires because they produced 
a rougher ride when compared to the "soft" rides of bias tires; moreover, they did not want to increase production costs of autos by incorporating the more expensive radial tires (Love and Giffels 1999).

Following the shift in demand for more fuel-efficient cars among American consumers, Japanese and European imports surged from 15.3 percent of U.S. auto sales in 1973 to 28 percent by 1980 (Love and Giffels 1999). Despite a brief rebound for U.S. automakers in the mid-1980s, these trends continued for the next three decades; by 2009, the "Big Three" (Ford, General Motors, and Chrysler) American automakers' share of the U.S. auto market had plummeted to roughly 45 percent, while the combined market share of Japanese, German, and Korean automakers reached approximately 47 percent (Wall Street Journal 2009). BF Goodrich closed its Akron factory in 1975, and by 1987 all of the tire manufacturers with the exception of Goodyear had closed or moved to nonunion cities and regions. Akron's overall rubber employment had plummeted to less than 15,000 jobs - accounting for more than half of the nation's job losses in the rubber industry (Love and Giffels 1999). Meanwhile, the city's business and civic community—historically led by rubber industry patriarchs (Allen 1949; Love and Giffels 1999) — was in disarray.

In 2009, Akron's base economy is largely transformed. Apart from Goodyear, the last remaining tire manufacturer in Akron, the largest nongovernment employers are in the health care (Summa Health System, Akron General Hospital, and Akron Children's Hospital) and higher education (University of Akron) sectors. Indeed, Akron's physical urban structure largely reflects this economic transformation with the hospitals centrally located in and around the city center (Figure 1). New health-care facilities now occupy previously blighted buildings and parcels. The University of Akron, located adjacent to downtown, has meanwhile expanded its reach into heart of the city center. The College of Business Administration building opened in the city center in 1991, and the university opened classrooms and other facilities in the former Polsky's department store building in 1994, which previously stood empty and boarded-up and was a major blight in the city following the closing of Polsky's in 1978. And in 2007, the university took over the once-revitalized Quaker Square Hotel (formerly a grain silo), turning half of its rooms into a dormitory for honors students. Finally, the University of Akron opened a new football stadium in 2009 on the southeastern edge of campus within the city of Akron.

This transformation of the economic and urban landscape of Akron has not been without problems. As mentioned, the former Quaker Oats grain silos in downtown Akron - a historical landmark - was converted into a hotel in 1980 after sitting idle for a decade. The hotel never quite flourished and was financially 


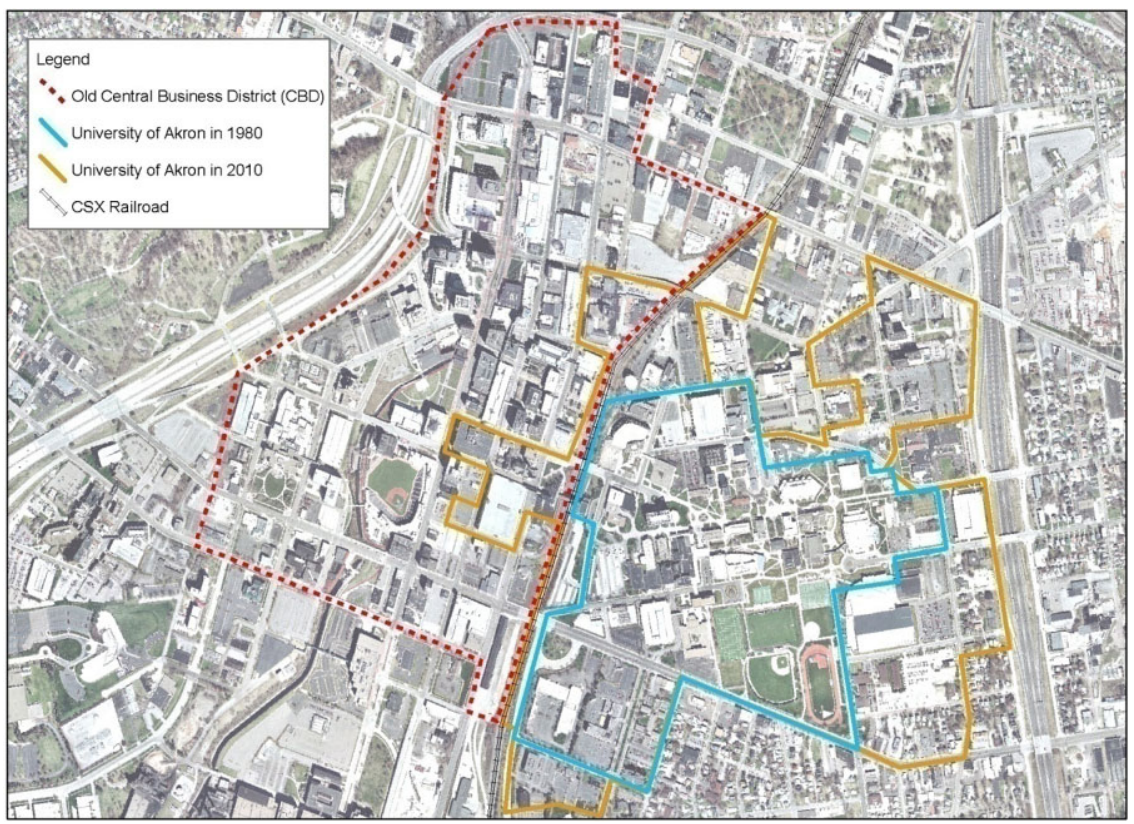

Figure 1. EXPANSION OF THE UNIVERSity OF AKRON AND HEAlTh CARE FACILITIES IN AKRON CITY CENTER, 1980-2010.

struggling by the late 1990s and early 2000s before being purchased by the University of Akron. In 1995, the city lured the National Inventors Hall of Fame by raising $\$ 38$ million through both public and private donations to build a state-of-the-art facility to house the museum. It never turned a profit, however, and lack of attendance caused the facility to be seen as a major boondoggle, and in 2009, the Inventors Hall of Fame pulled out of the building and out of Akron altogether after struggling there for more than a decade. University Park Alliance, meanwhile, is a project undertaken by the University of Akron in partnership with the city and community foundations to revitalize the University Park neighborhood that is located astride the university campus. University Park Alliance envisions a mixed-use housing development comprised of townhouses and retailers targeting the households of professional practitioners in the university and health-care communities. The project began in 2000 and has raised more than $\$ 150$ million, but it has yet to produce the kinds of neighborhood revitalization envisioned by the alliance organization.

Despite such failures and false starts - which arguably can be expected in a city struggling to revitalize-Akron is widely recognized as thus far successful in its 
efforts to restructure its economy. Particularly interesting in Akron's restructuring around the health care and higher education sectors-a project that remains a work-in-progress - is the seemingly steadfast commitment to a particular vision of the city's economy that now spans more than two decades. This is remarkable given that the city's leading economic anchors - the owners, after all, of the kinds of resources necessary for such an undertaking (Imbroscio 1998; Stone 2001)have been in flux for quite some time. One constant, however, is the administration of Mayor Plusquellic, now entering its twenty-fifth year. This is important not in the sense that the project to revitalize the city of Akron in a particular way necessarily rests with a single visionary; rather, the importance of Plusquellic's longevity is primarily one of offering political stability in a broader coalition whose economic partners were anything but stable. Indeed, following the collapse of the rubber industry and, subsequently, the civic community, the City of Akron struggled to harness the kinds of resources necessary to govern let alone transform its base economy. What followed then was a period in the 1980s and 1990s in which the old guard withered away and a new economic elite emerged - but not without stops and starts. Elected with the unenviable mandate of restructuring the Akron economy in the face of a collapsed rubber industry, the Plusquellic administration entered into partnerships with business leaders who could offer a degree of stability in terms of jobs and economic growth potential. Such leaders were not immediately obvious; indeed, a period of uncertainty persisted until a clearer picture of economic actors with more stable resources began to emerge. Interestingly, these actors were not found in the traditional private sector. Rather, local hospitals and the University of Akron increasingly set themselves apart from other actors in terms of employment stability and growth. By 2009, these two sectors are at the forefront of Akron's economic restructuring and, indeed, are central to the present political coalition, or urban regime, governing Akron (de Socio 2010). The resources that these sectors provide include job stability and growth on the one hand, and city center land use on the other. It is to this point - the importance of resources in regime networks - that the paper now turns.

\section{Urban Regimes as Resource-Rich Social Networks}

Resources are among the most important of factors shaping urban regimes (Stone 1993). Indeed, particular kinds of resources are needed for sustained political commitments like restructuring a city's economic base-resources such as the provision of jobs, providing campaign funds, the donation of staff time to civic activities, management skills, technical expertise, social contacts, philanthropy, and the like (Stone 1989; Stone, 2005). Such resources are typically found among the largest of corporations and civic organizations (Mills 1956; Orr and 
Stoker 1994; Stone 2001; Useem 1984), representing a terrible irony for a city like Akron and other deindustrializing communities whose very corporate resources are deteriorating and whose deterioration provides the conditions in which economic restructuring is necessary. In this sense, the downward spiral of so many deindustrializing cities-like New Haven (Fainstein et al. 1986), Detroit (Hill 1986; Orr and Stoker 1994), and Cleveland (de Socio 2007, 2010)-are exacerbated further by the lack of stable business partners that can match the once-robust resources of former economic giants who represented the base economy in years past. In Detroit, for example, Orr and Stoker (1994) note that the Big Three automakers based in the city remain a crucial part of Detroit's regime; the funding they provide to various civic organizations and revitalization initiatives dwarf such contributions from any other source. But their resources are limited:

They are increasingly preoccupied, struggling to survive in a changing world economy. After a partial recovery in the mid-1980s, the Big Three auto companies have faced major losses and plant closures in recent years. Thus, although they were prepared to fund some schemes, such as the Detroit Compact [a college scholarship program for qualifying local high school graduates], they were not prepared to promise jobs to compact students. As one executive put it: "How can we promise these kids jobs while we're laying their parents off?" (Orr and Stoker 1994: 58)

Like Akron, leadership in Detroit's revitalization efforts consequently rested with the mayor - in this case, Coleman Young. The Young administration pursued federal and state funding where possible and partnered with city center landowner interests in an ad hoc way, developing different partners for specific - usually cultural and/or entertainment-based — projects (Orr and Stoker 1994: 60). These types of projects typically target a highly educated and skilled labor force, or the "creative class" of emerging sectors like health care, telecommunications, and high-technology manufacturing (Florida 2002; Strom 2002). Other partners included banks and utilities, each interested in a viable regional economy and workforce. Yet, neither the banks and utilities, nor cultural and entertainmentbased development projects, provide a stable and growing source of employment like the automobile industry once did. Rather, banks, utilities, and cultural and entertainment projects are service industries whose viability rests on other, preferably broader and more economically diverse, sets of economic anchors than currently exists in Detroit. In short, Detroit's business community is "resource-poor" given the deteriorating nature of Detroit's largest corporations, and thus the Young administration is forced to seek whatever partnerships it can elsewhere.

While the availability of resources is clearly important in terms of regime formation, their existence alone does not in and of itself translate into the making 
of a regime coalition. Rather, regime formation is a political project requiring the mobilization of such resources, particularly the actors who command them. Stone (2001: 26), for example, writes that "problems are not self-defining and that some set of actors must frame problem-solving in such a way that a supporting coalition can be mobilized." In the case of Akron, for example - a case where the need for economic restructuring appeared so obvious that it might have seemed to have written itself - the kind of economic restructuring (and for whom) was anything but obvious. While the Plusquellic administration's operating motif of general economic restructuring was widely embraced, the policy of restructuring around a narrow set of economic actors was a policy agenda constructed and marketed in a way as to elicit engagement from actors with the kinds of resources that could bring such a policy agenda to fruition. This includes the bringing together of actors who command significant resources through the development of partnerships that allows for the dissemination of knowledge and information, and the identification and linking of needs with available resources. For example, "political and civic leaders need access to resources and expertise; business elites need access to policy makers and decision makers at city, regional, and state levels. [Partnerships] provide important structural vehicles on which urban governance and regime dynamics ride" (Austin and McCaffrey 2002: 35).

Regime partnerships are, by definition, part formal and part informal. While the formal component represents both elected and nonelected municipal government officials and government institutions, the informal component arises through the broader regime coalition that includes actors in the private and civic sectors outside of formal municipal government-actors who bring privately held resources into the coalition which, in partnership with municipal government, create a regime's capacity to govern. The scope of resources necessary for the creation of a capacity to govern - particularly if the policy agenda is economic restructuring - is typically bound-up with corporations and other large institutions (Mills 1956; Orr and Stoker 1994; Stone 2001; Useem 1984). Thus, the leaders of the largest corporations and civic and community organizations tend to be participants in most regime coalitions (Imbroscio 1998). However, although the relationships between corporate, civic, and community leaders and government are seen as informal and operating outside of the formal structures of municipal government, they do not materialize out of thin air. Rather, they arise within the wider context of regulated capitalism (de Socio 2010). For example, corporations and nonprofit civic and community organizations are mandated by federal commerce and tax laws to establish independent boards of directors in order to protect the interests of stockholders, donors, and investors (Meyer 2000; Zacharias 2000), direct corporate strategies (Oliver 2000), and appoint, evaluate, and determine 
compensation for corporate officers (Young, Stedham, and Beekun 2000). Those who are called upon to serve on corporate and civic organizations' boards of directors themselves typically possess the expertise and experience that comes with managing large corporations and/or civic organizations. Indeed, only a relatively small group of individuals in a city tend to possess such expertise and experience - usually, other corporate CEOs and top executives, directors of major civic organizations, and presidents of universities and other large institutions. Thus, leaders from this relatively small group are invited to serve as directors on one or more other corporate or organizational board, forming networks of corporations, civic organizations, universities, and other major organizations through shared, or "interlocking," directorates - and creating "informal" relationships (i.e., outside of the formal structure of government) between the various leaders of corporations, civic institutions and community organizations, and government (de Socio 2007; Useem 1984).

In addition, these "top" leaders who serve as directors also typically represent a particular social class - the business class - and are invited to serve as directors only after demonstrating a capacity to articulate the interests of the business class as a whole rather than parochially pursuing the interests of one's own corporation or industry solely (Domhoff 2005; Mintz and Schwartz 1985; Mizruchi 1992; Ratcliffe 1980; Useem 1984). Stone (1989: 170) writes, for example:

Within the business community, there are deliberate efforts to inculcate a group perspective and surmount the tendency to think parochially about one's own business firm. To rise to a position of general leadership, a business person is expected to pass through "rites" of service; that is, to play a number of specific business leadership roles - president of the Chamber of Commerce, board membership in [a pro-business policy organization], head of the fund drive for the United Way, head of [an arts organization], and perhaps serve on the board of various eleemosynary institutions.

Consequently, business leaders tend to also head or serve as directors on major charitable organizations (in the U.S., for example, the local or regional chapter of the United Way is typically the largest charity organization), community foundations, art museums and councils, and business policy organizations like Team NEO, an organization comprised of the CEOs of corporations based in Northeast Ohio who provide technical and management expertise to city officials, and which advocates on behalf of its corporate members when lobbying local, state, and federal government entities regarding policies that affect the corporate community (DiMaggio and Anheier 1990; Galaskiewicz and Bielefeld 1998; Martin 2004; Salzman and Domhoff 1980, 1983; Stone 1989).

Stone (1989) suggests that business and other community leaders are important to regime formation and maintenance relative to their degree of involvement in community affairs. "Involvement" for business leaders generally includes serving 
on the board(s) of one or more corporate or community organization, business policy organization, philanthropy organization, or the like, often across sectors, and otherwise becoming "plugged-in" with various other business and community leaders, thus generating an invaluable resource-rich social network comprised of elite actors who command the very resources necessary to generate a regime's capacity to govern (Stone 2001). In social network terminology, such cross-sector networks of actors comprising a regime's broader coalition represent "shared events" (Wasserman and Faust 1994) - the "event" is the sitting on one or more corporate or other organizational board. The actors considered to be the most important in such networks are those that have the highest number of links with other actors in the network; that is, they are connected to the greatest number of fellow directors by virtue of the number of boards they serve on. These are the "most visible" actors in the network and are, as Stone suggests, the "most involved" (Wasserman and Faust 1994). These are the more influential actors in the network, because information can quickly pass from them to their many fellow directors in their immediate network and on to other directors in the broader network of interlocking boards of directors.

Until recently, an explicitly network-based approach to regime analyses has been wholly absent despite the clear articulation of network principles inherent in regime theory. However, a recent study utilizing social network analysis to identify the most central of actors - the most influential - in the contemporary regime coalitions of Akron and Cleveland found that business leaders affiliated with traditional manufacturing are largely marginalized in both networks in favor of business leaders affiliated with "newer" economic activities of a more stable and robust nature, namely heath care and higher education (de Socio 2010). This study takes the next step by looking backward; that is, by exploring the networks of interlocking directorates through previous decades beginning with the 1970s when the tire manufacturers-while collapsing as an industry — were still the most prominent economic activities found in Akron. It is hypothesized that the tire manufacturers-like the deteriorating auto industry in Detroit (Orr and Stoker 1994) - continued to play a crucial part in Akron's regime coalition and remained the most influential economic partners even as they were in the midst of rapid decline.

\section{Data and Methodology}

Two important concepts in social network analysis are centrality and density. Regarding centrality, perhaps the primary use of social network theory is the identification of the "most important," or "most influential," actors in a network (Wasserman and Faust 1994). Importance and influence arises through strategic 
locations within a network. To the extent that an actor has influence in a network, he/she is regarded as central or possessing centrality. Centrality is measured as degree, betweenness, and "flow betweenness." "Degree centrality" indicates the measure of a node's positionality in an overall network of interconnected entities by simply counting the total number of ties a node has with other entities in the network - like the number of fellow directors one is linked with by virtue of the number of boards one serves on. Entities with a low number of ties are considered to be marginal within the network in which it belongs; conversely, the higher the number of ties, the more important an entity is by virtue of its connectedness with other entities in the network. These are the most involved entities and the most influential because information can easily pass from them to many other entities in the network. "Betweenness centrality" measures the extent to which a particular node lies "in between" all other nodes in the network. For example, an entity with a relatively few number of ties (or a relatively low degree centrality score) may be strategically positioned within the network so that information between other nodes must pass through it. Serving as a sort of bottleneck between separate clusters of entities, nodes with high betweenness scores essentially act as "gatekeepers" of information flow between groups of interconnected nodes within the network. In more technical terms, betweenness centrality measures the number of geodesics (or shortest pathways) between any pair of nodes in the network, and consequently, the extent to which a particular entity lands on the shortest path between two other nodes. If one conceptualizes a network as pipes through which information flows, the flow can be reversed with information flowing in the opposite direction. Thus backward flow betweenness centrality might produce a different order of central actors; nevertheless, the three measures of centrality, including backward flows, generally reinforce and complement each other. Finally, density is a ratio of the number of actual ties within a network and the sum of all possible ties. Density takes on a value between 0 and 1 ; the closer to 1 , the more dense the network.

Data on interlocking directorates for Akron came from the Standard \& Poor Index of Corporations and Directors volumes for the years 1975, 1985, 1995, and 2006. The index of corporations lists all of the companies located in the City of Akron and their directors and executives. The index of directors lists all of the companies and institutions for which an individual director or executive serves as a director elsewhere. Table 1 lists all of the companies for the years 1975 through 1995 in which at least one executive or director served as a director for another company or organization also based in Akron, creating a network of companies and organizations. Further, as with any social network analysis, among the first problems to overcome is to identify the network and limit its extent for analysis. 
TABle 1. Interlocked COMPANies BASEd IN AKRON.

\begin{tabular}{lll}
\hline 1975 & \multicolumn{1}{c}{1985} & \\
\hline $\begin{array}{l}\text { A Schulman, Inc. } \\
\text { Akron Canton \& Youngstown RR. }\end{array}$ & A Schulman, Inc. & A A Schulman, Inc. \\
Akron Chemical Co. & Akron Coca-Cola Bottling Co. & Akrochem Corp. \\
Akron Equipment Co. & Akron Equipment Co. & Bank One of Akron, N.A. \\
Akron Metal Etching Co. & B. F. Goodrich Co. & First Bancorporation of Ohio \\
Akron National Bank \& Trust Co. & Bank One of Akron, N.A. & First National Bank of Ohio \\
Akron Savings \& Loan & Burger Iron Co. & Georgia Gulf Sulfur Corp. \\
B. F. Goodrich Co. & Central Bank of Akron & Goodyear Tire \& Rubber Co. \\
C C C Rental, Inc. & Firestone Tire \& Rubber Co. & Harwick Chemical Corp. \\
Central Bank of Akron & First Bancorporation of Ohio & Ohio Edison Co. \\
City Chevrolet Inc. & First National Bank of Akron & Pulaski Rubber Co \\
Detroit Free Press, Inc. & Gencorp, Inc. & R. C. A. Rubber Co. \\
Firestone Bank & Goodyear Tire \& Rubber Co. & Resource America Inc. \\
Firestone Tire \& Rubber Co. & McNeil Corp. & Revlis Corp. \\
First National Bank of Akron & Myers Industries & Roadway Express, Inc. \\
Fred W. Albrecht Grocery Co. & National City Corp. & Roadway Services, Inc. \\
General Tire \& Rubber Co. & Ohio Edison Corp. & The Kroger Co. \\
Goodyear Bank & R. C. A. Rubber Co. & \\
Goodyear Tire \& Rubber Co. & Revlis Corp. & \\
Hardware \& Supply Co. & Roadway Express, Inc. & \\
Knight Publishing Co. & Roadway Services, Inc. & \\
Kraftco Corp. & Rohrich Corp. & \\
Miami Herald Pub. Co. & Rubber Manufacturers Assn & \\
Nobil Shoe Co. & The Arnold Corp. & \\
Ohio Edison Co. & Transco Plastics Corp. & \\
Roadway Express, Inc. & & \\
Rohrich Corp. & & \\
Rubber Manufacturers Assn. & & \\
The Beacon Journal Publishing Co. & & \\
\hline
\end{tabular}

Interlocking directorates, for example, link not only corporations and organizations at the local and regional levels but also connect firms and organizations nationally and globally (de Socio 2010). For example, although interlocks link individuals across scales that potentially represent additional resources within a network's reach, the degree of overlapping firms and organizations diminishes quite rapidly with increasing distance from the metropolitan scale. Additionally, directors operating at the local and regional scales are widely regarded as stakeholders in their communities with their professional and personal fortunes tied, more or less, to the overall vibrancy of the regional economy in which their firms and organizations are embedded through suppliers, commodity chains, labor forces, agglomeration economies, and so on (Cox and Mair 1988; Scott 2001; 
Storper and Venables 2004). Firms and organizations outside of the Akron metropolitan area, then, are not considered in the analysis, even though such firms and organizations may have a director serving on their board who is based outside of Akron.

While a regime coalition is comprised of individuals across sectors, only data regarding companies was collected for the years 1975 through 1995. Data availability from years past for civic organizations, business policy organizations, eleemosynary institutions, and the like is highly inconsistent. For 2006, data is included from across the three broad sectors of corporations, business policy organizations, and civic organizations and universities (Table 2). To the extent of data from the noncorporate sector that is absent from the years 1975 through 1995, literature on relationships between the nonprofit sector and the corporate sector find strong linkages between firms and large cultural institutions through interlocking corporate directors and organizational and university trustees (DiMaggio and Anheier 1990; Galaskiewicz and Bielefeld 1998; Martin 2004; Salzman and Domhoff 1980, 1983; Stone 1989). Consequently, it is expected that such institutions would emerge in a social network analysis relative to their degree centrality if such organizations are heavily represented on various corporate boards, and/or if the corporate community is heavily represented on the boards of such noncorporate sector organizations. Nevertheless, this shortcoming

TABle 2. InTERlocked CORPORATIONS, CiVIC ORganizATIONS AND BUSINESS Policy ORganizATIONS BASEd IN AKRON, OHIO, IN 2006.

\begin{tabular}{|c|c|c|}
\hline Corporations & $\begin{array}{l}\text { Civic organizations } \\
\& \text { universities }\end{array}$ & $\begin{array}{l}\text { Business policy } \\
\text { organizations }\end{array}$ \\
\hline A. Schulman & Akron Art Museum & Akron Roundtable \\
\hline $\begin{array}{l}\text { Akron General Health } \\
\text { System }\end{array}$ & $\begin{array}{l}\text { Akron Community Foundation } \\
\text { Knight Foundation }\end{array}$ & $\begin{array}{l}\text { Downtown Akron } \\
\text { Partnership }\end{array}$ \\
\hline Diebold & Kent State University & Greater Akron $\mathrm{CoC}$ \\
\hline FirstEnergy & Summa Hospitals Foundation & NorTech \\
\hline FirstMerit Bank & The University of Akron & Team NEO \\
\hline OMNOVA Solutions Inc & United Way of Summit County & \\
\hline Summa Health System & University of Akron Foundation & \\
\hline $\begin{array}{l}\text { The Goodyear Tire \& } \\
\text { Rubber Co. }\end{array}$ & Akron Art Museum & \\
\hline The Timken Company & & \\
\hline
\end{tabular}


in data availability might adversely minimize the centrality of noncorporate sector organizations for the years prior to 2006 .

The number of companies chosen for 1975, 1985, and 1995, respectively are 29,25 , and 17 , and the combination of companies and noncorporate sector entities chosen for 2006 numbers 22 (or nine companies, eight civic organizations and universities, and five business policy organizations). For each of the 4 years in which data was collected, a bipartite matrix was constructed with the corporations (and nonprofit sector organizations for 2006) occupying the columns and individual directors occupying the rows. For 1975, the number of individual directors or executives affiliated with one of the 29 companies and who serve as a director or on at least one other of the 29 companies listed is 91 . For 1985 and 1995, the numbers are 95 and 38, respectively. Thus, 29 by 91,25 by 95 , and 17 by 38 bipartite matrices were constructed for the years 1975, 1985, and 1995, respectively. For 2006, a much fuller data set consisting of three broad sectors of corporations, civic organizations and universities, and business policy organizations, was constructed; the number of directors and executives affiliated with one of the 22 cross-sector organizations and who serve as a director or on at least one other of the 22 companies listed is 253 . Thus, for 2006, a 22 by 253 bipartite matrix is constructed. Using the bipartite matrices, a single matrix matching up director names and counts for shared numbers of boards served on was constructed for each year (91 by 91 for 1975, 95 by 95 for 1985, 38 by 38 for 1995, and 253 by 253 for 2006). For each of the four matrices, social network analysis was performed using the software program UCINET 6.0 (Borgatti, Everett, and Freeman 2002).

\section{Results}

For networks the size of regime coalitions, network densities would generally be small given the total number of possible ties that such large networks typically entail. Centrality in such low-density networks would usually be considered lessened and power more widely dispersed. The densities of Akron's regime network for each of the years studied are 0.0994 (1975), 0.097 (1985), 0.1351 (1995), and 0.190 (2006). A secondary measure of overall centralization within a network - or a measure of power concentration among a few actors-is network centralization, an index which again takes on a value between 0 and 1 and which also would be expected to be relatively small given the generally large size of regime networks. The network centralization index for each of the years studied are 0.0443 (1975), 0.0768 (1985), 0.0571 (1995), and 0.1372 (2006). Both indices are higher for 2006-a network database more than six times larger than 1995 , the year with the smallest network database - indicating that power is more 
concentrated among fewer actors relative to the previous years despite being a much larger network for analysis. The network database for 2006 is much more robust, however, and includes a wider spectrum of actors across sectors, arguably capturing a more comprehensive picture of regime participation - and, subsequently, arguably capturing more specific loci of power within the network. Nevertheless, the indices-including 2006-remain generally small as expected. Indeed, to the extent that centrality would emerge in regime networks, regime theory suggests that key actors, though lacking in "power over," facilitate information dissemination and exchange, and are therefore strategically positioned to mobilize the regime network on behalf of particular issues or policy agendas (Stone 1989, 2006). Hence, centrality measures are a better indicator of the influence of individual actors relative to all other actors in the network.

Stone (1989) contends that business and community leaders are "central" to regimes relative to the degree of their involvement-if they choose to be involved at all - in the wider community. For business leaders, involvement in the wider community often equates with serving as a director on one or more corporate or organizational boards and across sectors. The more boards on which one serves, the more directors one is directly connected to, and hence the more "central" one is within the overall network. Immediate linkages between one director and his/her fellow directors serving together on one or more boards comprise an individual director's degree centrality. Table 3 lists the company and organizational affiliations of directors in Akron for each of the 4 years who serve on the most boards. Table 4 through 7 list the top 7 to 10 (established by natural breaks) companies and organizational affiliations for directors ranked by the three measures of centrality for each of the years 1975 (Table 4), 1985 (Table 5), 1995 (Table 6), and 2006 (Table 7). Degree centrality — the first measure of centrality in Table 4 through 7-simply measures how many other directors a single director is connected to by virtue of the number of boards he/she serves on. For example, in 1975, a partner in the law firm of Brouse McDowell served on five boards (Table 3) and, consequently, was directly linked to 30 other directors (Table 4). In 1985, meanwhile, a partner in the law firm Buckingham Doolittle \& Burroughs served on five boards (Table 3) and, consequently, was directly linked to 37 other directors (Table 5). And so on.

Regarding numbers of boards served on (Table 3), it is noteworthy that individuals representing tire, rubber, and/or polymer manufacturers served on a total of 9 boards in 1975, 14 boards in 1985, none in 1995, and 4 in 2006. Directors who represent manufacturing in general (including chemicals, tires, and rubber) served on a total of 9 boards in 1975, 20 boards in 1985, 9 in 1995, and 8 in 2006. Tire manufacturers and manufacturing in general, meanwhile, dominated measures of 


\section{NETWORK RESTRUCTURING IN AKRON, 1975-2009}

TABle 3. COMPANy AND ORganizational AFFiliations of Directors in AKRON WHO SERVED ON THREE OR MORE BOARDS (1975-1995), OR FOUR OR MORE BOARDS (2006).

1975

Brouse McDowell

Akron Beacon Journal

Akron Beacon Journal

City Chevrolet

Ohio Edison

General Tire

The Goodyear Tire \& Rubber Co.

BF Goodrich

1985

Buckingham Doolittle \& Burroughs

A Schulman, Inc.

Roadway Express

The Goodyear Tire \& Rubber Co.

Brouse McDowell

Myers Industrials

General Tire

R.C.A. Rubber Co.

First Merit Bank

Ohio Edison

McNeil Corp.

1995

Ohio Edison

Buckingham Doolittle \& Burroughs

First Merit Bank

Harwick Standard

Akrochem

Akrochem

Watkins Norma L.

2006

Amer Cunningham \& Brennan

The University of Akron

Summa Health System

Ernst \& Young LLP

Brouse \& McDowell LLP

Akron Community Foundation

Akron General Health System

Greater Akron Chamber of Commerce

Akron Children's Hospital

Akron Beacon Journal

FirstEnergy

The Goodyear Tire \& Rubber Company

Stark \& Knoll Co LPA

RPM International Inc.
Law firm 5

Publishing 4

Publishing 4

Car dealership 3

Energy 3

Tire manufacturing 3

Tire manufacturing 3

Tire manufacturing 3

Law firm 5

Polymer manufacturing 5

Transportation 4

Tire manufacturing 3

Law firm 3

General manufacturing 3

Tire manufacturing 3

Rubber manufacturing 3

Banking 3

Energy 3

General manufacturing 3

Energy 3

Law firm 3

Banking 3

General manufacturing 3

Chemicals 3

Chemicals 3

Law firm 6

Higher education 6

Medical 6

Accounting 5

Law firm 5

Civic 4

Medical 4

Business policy organization 4

Medical 4

Publishing 4

Utility 4

Tire manufacturing 4

Law firm 4

Manufacturing 4 
Table 4. Centrality Measures, 1975.

\begin{tabular}{llr}
\hline Director affiliation & \multicolumn{1}{c}{ Industry sector } & $\begin{array}{c}\text { Centrality } \\
\text { score }\end{array}$ \\
\hline Degree centrality & & \\
Brouse McDowell & Law firm & 30 \\
General Tire & Tire manufacturing & 23 \\
First National Bank of Akron & Banking & 20 \\
The Goodyear Tire \& Rubber Co. & Tire manufacturing & 20 \\
Roadway Express & Transportation & 20 \\
A Schulman, Inc. & Polymer manufacturing & 20 \\
Hardware \& Supply Co. & Manufacturing & 19 \\
Nobil Shoe Co. & Manufacturing & 19 \\
Betweenness centrality & & \\
Brouse McDowell & Law firm & 2,423 \\
Acme Groceries & Retail & 1,981 \\
Acme Groceries & Retail & 1,733 \\
Ohio Edison & Energy & 1,095 \\
General Tire Co. & Tire manufacturing & 1,062 \\
Summit Properties & Real estate & 936 \\
Acme Groceries & Retail & 814 \\
Backward flow betweenness centrality & & \\
Brouse McDowell & Law firm & 6,168 \\
Ohio Edison & Energy & 3,984 \\
General Tire Co. & Tire manufacturing & 3,946 \\
Acme Groceries & Retail & 3,816 \\
BF Goodrich Co. & Tire manufacturing & 3,218 \\
The Goodyear Tire \& Rubber Co. & Tire manufacturing & 2,770 \\
The Goodyear Tire \& Rubber Co. & Tire manufacturing & 2,760 \\
\hline & & \\
& &
\end{tabular}

degree centrality in 1975, 1985, and 1995 (Table 4 through 6) but dropped off dramatically in 2006; indeed, only the Goodyear Tire \& Rubber Company remains in business, let alone active as a business partner in Akron's regime coalition by 2006. BF Goodrich remained part of Akron's network of interlocking directorates in 1995 despite having moved its headquarters to suburban Richland, Ohio, on the outskirts of Akron. In this simple count of boards served on and corresponding degree centralities, tire manufacturers clearly dominated Akron's business 
Table 5. Centrality Measures, 1985.

\begin{tabular}{lcc}
\hline Director affiliation & $\begin{array}{c}\text { Centrality } \\
\text { score }\end{array}$ \\
\hline
\end{tabular}

Degree centrality

Buckingham Doolittle \& Burroughs

A Schulman, Inc.

Roadway Express

Law firm

Polymer manufacturing

Transportation

The Goodyear Tire \& Rubber Co.

Tire manufacturing

Ohio Edison

Energy

General Tire Co.

Tire manufacturing

First Merit Bank

Banking

Betweenness centrality

Brouse McDowell

Law firm

6,168

Ohio Edison

Energy

3,984

General Tire Co.

Tire manufacturing

3,946

Acme Groceries

Retail

3,816

BF Goodrich Co.

The Goodyear Tire \& Rubber Co.

The Goodyear Tire \& Rubber Co.

Tire manufacturing

3,218

Tire manufacturing

2,770

Tire manufacturing

2,760

Backward flow betweenness centrality

A Schulman, Inc.

Polymer manufacturing $\quad 5,442$

BF Goodrich Co.

Tire manufacturing

3,614

BF Goodrich Co.

Tire manufacturing

3,614

General Tire Co.

Tire manufacturing

3,546

McNeil Corp.

General manufacturing

3,300

The Goodyear Tire \& Rubber Co.

Tire manufacturing

2,700

The Goodyear Tire \& Rubber Co.

Tire manufacturing

2,700

The Goodyear Tire \& Rubber Co.

Tire manufacturing

2,700

community prior to the 2000s. While one of its executives served on as many as four boards in 2006, the Goodyear Tire \& Rubber Company-historically the city's largest private-sector employer (and which still ranked third in 2006) - had the lowest degree centrality (less than 100) of Akron's leading institutions. In contrast, the University of Akron had a degree centrality score of 187 and Summa Health System had a degree centrality score of 167 . This is significant given the physical expansion of both local hospitals and the University of Akron into the heart of Akron's city center in recent years (Figure 1). 
Table 6. Degree Centrality, 1995.

\begin{tabular}{llr}
\hline Director affiliation & \multicolumn{1}{c}{ Industry sector } & $\begin{array}{c}\text { Centrality } \\
\text { score }\end{array}$ \\
\hline Degree centrality & & \\
Buckingham Doolittle \& Burroughs & Law firm & 31 \\
Ohio Edison & Energy & 31 \\
First Merit Bank & Banking & 29 \\
Roadway Express & Transportation & 26 \\
Roadway Express & Transportation & 26 \\
Harwick Standard & General manufacturing & 26 \\
Akrochem & Chemicals & 26 \\
Roadway Express & Transportation & 26 \\
BF Goodrich Co. & Tire manufacturing & 25 \\
BF Goodrich Co. & Tire manufacturing & 25 \\
Betweenness centrality & & \\
Ohio Edison & Energy & 236 \\
Buckingham Doolittle \& Burroughs & Law firm & 235 \\
A Schulman, Inc. & Polymer manufacturing & 158 \\
Harwick Standard & General manufacturing & 64 \\
Roadway Express & Transportation & 32 \\
Roadway Express & Transportation & 32 \\
Roadway Express & Transportation & 32 \\
Backward flow betweenness centrality & & \\
Ohio Edison & Energy & 552 \\
Buckingham Doolittle \& Burroughs & Law firm & 552 \\
A Schulman, Inc. & Polymer manufacturing & 348 \\
Harwick Standard & General manufacturing & 134 \\
Roadway Express & Transportation & 86 \\
Roadway Express & Transportation & 86 \\
Roadway Express & Transportation & 86 \\
\hline
\end{tabular}

Regarding betweenness centrality, measuring how close one particular director is to all other directors in the full network of interlocking directorates by counting the geodesic distances from one particular node to all other nodes in the network, tire manufacturing dominates only in 1985. However, in measures of "backward flow" betweenness centrality, tire manufacturing once again thoroughly dominates in 1975 and 1985 but is absent in 1995. The Goodyear Tire \& Rubber Company 
Table 7. Centrality Measure, 2006.

\begin{tabular}{lcc}
\hline Director affiliation & Industry sector & $\begin{array}{c}\text { Centrality } \\
\text { score }\end{array}$ \\
\hline
\end{tabular}

Degree centrality

The University of Akron

Higher education

187

Ernst \& Young

Accounting firm

177

Summa Health System

Health care

167

Akron Community Foundation

Civic organization

142

Greater Akron CoC

Business policy org.

124

Government

114

Banking

113

Government

112

Health care

112

Law firm

109

Tire manufacturing

Betweenness centrality

Ernst \& Young

The University of Akron

The Goodyear Tire \& Rubber Co.

Accounting firm

6,475

Higher education

5,160

Tire manufacturing

Summa Health Systems

Health care

4,155

Civic organization

2,511

Akron Beacon Journal

Publishing

2,314

The Goodyear Tire \& Rubber Co.

Tire manufacturing

2,251

National City Corp.

Banking

1,871

Higher education

1,792

City of Akron

Government

1,621

Backward flow betweenness centrality

The University of Akron

Ernst \& Young

The Goodyear Tire \& Rubber Co.

Summa Health System

Higher education

27,204

Accounting firm

25,146

Tire manufacturing

24,092

Health care

21,714

Amer Cunningham \& Brennan

Law firm

21,204

Akron Community Foundation

Civic organization

21,122

City of Akron

Government

16,478

First Merit Bank

Banking

16,216 
reemerges in 2006 as a leading member of Akron's business network, but its presence is diluted by a range of other-largely health care, higher education, and nonprofit—organizations.

\section{Discussion}

The economic and urban landscape of Akron, Ohio has largely transformed over the past 30 years. The collapse of Akron's tire and rubber manufacturing industry - an industry that once was as important to Akron's economy as automobiles were for Detroit-forced elected officials to forge partnerships with a different, if not wider, set of private actors in order to effectively respond to changing economic realities. The Plusquellic administration, first elected in 1986, is now into its twenty-fifth year of managing Akron's economic transition away from tire and rubber manufacturing and toward something different. Much like the Young administration in Detroit (Orr and Stoker 1994), the Plusequllic administration initially entered into partnerships with city center stakeholders in an ad hoc fashion that focused primarily on restructuring land uses in the downtown district. The sprawling former BF Goodrich complex, comprised of nearly 30 mostly brick buildings, was purchased by Covington Capital Group in 1993 with the full support of the Plusqeullic administration, turning the 35-acre complex into a light industrial park known as Canal Park and now home to various companies and branch operations (Hill 2009; Love and Giffels 1999). Canal Park Stadium, meanwhile, was built partly with city money for a minor league baseball affiliate of the Cleveland Indians and opened in 1997 adjacent to the old BF Goodrich facility in the heart of the downtown.

But it is the rise of health care and higher education as central components of restructuring around which the Plusquellic administration has constructed an "identifying agenda" for which to mobilize actors and galvanize support for its efforts at revitalizing the city's economy. Mobilization is itself a major undertaking requiring both political skill and acumen, and marketing skills as well—or, as Stone (2001: 21) puts it, the ability to produce an identifying agenda that captures "the problem at hand," often with a relatively simple catchphrase or slogan (like "the city too busy to hate" used by Atlanta in the 1950s and 1960s; or "the city that works" used by the Richard Daley administration in Chicago). Further, the identifying agenda must be linked to a concrete course of action "through which diverse bases of support are gained and maintained" (Stone 2001: 21). In Akron, the Plusquellic administration's concept of developing a "biomedical corridor" around a segment of the downtown has succinctly captured both contemporary trends in Akron's base economy and a unifying vision of the city's future. The idea is to encourage further land use changes in the downtown area around the 
hospitals and health care facilities already located in the city toward the creation of a localized agglomeration economy centered on health care (US States News 2006). Further, the biomedical corridor project allows Akron to forge partnerships with actors in the wider, regional, community encompassing the combined AkronCleveland metropolitan area of Northeast Ohio. In Cleveland, for example, revitalization efforts increasingly focus on the areas immediately adjacent to the famous Cleveland Clinic hospital complex which, like the hospitals in Akron, has been a source of stable high-skilled employment and growth. Business relations between Akron and Cleveland's health-care industries are increasing with the support of the mayor administrations of both Akron and Cleveland.

The Plusquellic administration's biomedical corridor concept has wide support among the city's business and community leaders. Summa Health System has expanded its operations within the corridor, even moving operations into the city's old post office building, a historical landmark (US States News 2007a). Addition-

ally, Summa Health System and Akron General Hospital entered into a partnership for the development of a new acute care facility to be built within the biomedical corridor (US States News 2007b). A biomedical firm based in New Jersey, meanwhile, committed to relocating its medical manufacturing operations to a site within the corridor (Powell 2007).

Akron's continuing focus on the health-care sector also "piggy-backs" on high-technology spin-off operations from its former tire and rubber manufacturing sector. The polymer industry is an outgrowth of tire and rubber manufacturing. The Goodyear Tire \& Rubber Company, for example, is the last remaining tire manufacturer based in the city. Yet, even if it no longer makes tires in the area, rather, its Akron facilities focus primarily on the research and design of polymers - malleable sticky rubbery substances that are chemically producedwhich have multiple high-technology applications in aerospace, defense, and health care. Applications in health care, for example, include uses for medical machinery and prosthetics. Meanwhile, Goodyear partnered with the University of Akron in the creation of the College of Polymer Science and Polymer Engineering, and built the futuristic-looking Goodyear Center for Polymer Research office tower, which opened in 1991, straddling both the university campus and downtown Akron.

\section{Conclusion}

Business community leaders are typically seen as important members of most regime coalitions due to the kinds of resources they command. Yet, capitalism is a dynamic force imposing all sorts of pressures on corporations for change, whether to reduce production costs, develop new product lines, or alter marketing 
strategies, etc., often leading to disinvestment in some places and new investment in others. While entire industries decline as a result of changing economic realities, the business partners of regime coalitions affiliated with such sunset industries consequently command resources that are deteriorating in quality and quantity (de Socio 2010), thus hamstringing cities caught up in, for example, deindustrialization, and paradoxically limiting their capacity to restructure their economies. Indeed, regarding the means to develop a coalition aimed at economic restructuring, "one or both partners, public or private, might lack the capacity or the resources or the opportunity to consummate an alliance" (Austin and McCaffrey 2002: 48). Such was the case for Akron and many other cities in the American "rust belt" where the "private" partner, the business community, experienced - and continues to experience - a prolonged period of economic upheaval.

Thus, regime partnerships are dynamic and change through time; they cannot remain static (Stone 1989: 9). While resources are key for regimes to develop and sustain a policy agenda, the kinds of resources attributed to business community leaders - for example, management skills, technical expertise, and organizational connections - are contingent upon the particular mix of corporations based in cities and the general economic health of both its firms and the wider economic sectors to which they belong (de Socio 2007). The paradox facing cities is that when the resources necessary for governing, let alone for initiating a major program like restructuring urban land uses and the economy, are themselves unstable and rapidly deteriorating in quantity and quality as the firms and industries to which they are attributed decline.

In Akron, the Plusquellic administration turned to the nontraditional "business" interests of its local hospitals and the University of Akron with which to forge partnerships for restructuring its base economy - a sort of reconceptualizing what economic resources entail (e.g., Imbroscio 2003). These partners are nontraditional in the sense that they are either nonprofit organizations (the hospitals) or a state-run institution (the university). Yet, the resources they command are valuable to a city struggling to revitalize. For example, while the University of Akron isn't growing in terms of its student population, it has been a pillar of economic stability amid the decline of Akron's tire and rubber industries. Further, the physical restructuring of its campus has enabled the university to assume control of several downtown properties in distress and to bring a vibrant student population into the city center, thus changing the character of the downtown as a place chockfull of activities for young people where previously blighted buildings have been refurbished and turned into university facilities. The hospitals, meanwhile, are growing, and they are part of a wider health-care industry that appears 


\section{NETWORK RESTRUCTURING IN AKRON, 1975-2009}

to be among the leading industries in terms of employment growth in a service economy (de Socio 2007; Hill 2009).

This transformation of Akron's regime partnership did not occur overnight, as the social network analysis demonstrates. Rather, the Plusquellic administration struggled to navigate challenging economic realities as it pressed forward with its mandate to restructure the local base economy even as it initially lacked the requisite partners who command the kinds of resources necessary to transform Akron's downtown land uses. Indeed, this study illustrates, through a longitudinal social network analysis, a changing of the guard in terms of business community leadership within Akron's interlocking network of corporations, from "rubber barons" in the 1970s and 1980s, to health-care and higher education leaders in the 2000s, with the 1990s representing a decade of transition. The utility of social network analysis is its ability to precisely situate the most prominent actors within a regime coalition, both currently and in the years past. What is less certain, however, is whether social network analysis allows for a proactive identification of actors who command the kinds of resources necessary for building and sustaining regime coalitions aimed at either restructuring a local base economy or otherwise aimed at enhancing the quality of life of citizens.

\section{REFERENCES}

Allen, H. 1949. The house of goodyear: Fifty years of men and industry. Cleveland: Corday \& Gross Company.

Austin, J., and A. McCaffrey. 2002. Business leadership coalitions and public-private partnerships in American cities: A business perspective on regime theory. Journal of Urban Affairs 24: 3554.

Borgatti, S., M. Everett, and L. Freeman. 2002. Ucinet 6.0 Version 1.00. Nantucket, MA: Analytic Technologies.

Brenner, N. 2009. Is there a politics of urban development? Reflections on the US case. In The City in American Political Development, ed. R. Dilworth, 121-140. New York: Routledge.

Burns, P., and M. Thomas. 2004. Governors and the development regime in New Orleans. Urban Affairs Review 39: 791-812.

Cox, K. 1997. Governance, urban regime analysis, and the politics of local economic development. In Reconstructing Urban Regime Theory: Regulating Urban Politics in a Global Economy, ed. M. Lauria, 99-121. Thousand Oaks, CA: Sage.

2004. The politics of local and regional development, the difference the state makes and the US/British context. In Governing Local and Regional Economies: Institutions, Politics and Economic Development, ed. A. Wood, and D. Valler, 247-275. Aldershot: Ashgate Publishing.

Cox, K., and A. Mair. 1988. Locality and community in the politics of local economic development. Annals of the Association of American Geographers 78: 307-325.

de Socio, M. 2007. Business community structures and urban regimes: A comparative analysis. Journal of Urban Affairs 29: 334-366. 
2010. Marginalization of sunset firms in regime coalitions: A social network analysis. Regional Studies 44: 167-182.

DiGaetano, A., and J. Klemanski. 1989. Power and city governance: Comparative perspectives on urban development. Minneapolis, MN: University of Minnesota Press.

DiMaggio, P., and H. Anheier. 1990. The sociology of nonprofit organizations and sectors. Annual Review of Sociology 16: 137-159.

Domhoff, G. 2005. Who rules America? Power, politics, and social change, 5th ed. Englewood Cliffs, NJ: Prentice-Hall.

Fainstein, N.I., S.S. Fainstein, R.C. Hill, D. Judd, and M.P. Smith. 1986. Restructuring the city: The political economy of urban redevelopment. White Plains, NY: Longman Group.

Florida, R. 2002. The rise of the creative class. New York: Basic Books.

Galaskiewicz, J., and W. Bielefeld. 1998. Nonprofit organizations in an age of uncertainty: A study of organizational change. New York: Aldine de Gruyter.

Hackworth, J. 2007. The neoliberal city: Governance, ideology, and development in American urbanism. Ithaca, NY: Cornell University Press.

Hanson, R., H. Wolman, D. Connolly, K. Pearson, and R. McManmon. 2010. Corporate citizenship and urban problem solving: The changing civic role of business leaders in American cities. Journal of Urban Affairs 32: 1-23.

Harvey, D. 1989. From managerialism to entrepreneurialism: The transformation in urban governance in late capitalism. Geografiska Annaler: Series B, Human Geography 71: 3-17.

Harvey, D. 2005. A brief history of neoliberalism. Oxford, UK: Oxford University Press.

Hill, E. 2009. Does a mayor make a difference in a city's economic performance? The case of Akron, Ohio. Report to the Building Resilient Regions Network, University of California at Berkeley. 06 May 2009. http://urban.csuohio.edu/publications/hill/mayor_make_a_difference_05_2009.pdf (accessed 7 August 2009).

Hill, R. 1986. Crisis in the motor city: The politics of economic development in Detroit. In Restructuring the city: The political economy of urban redevelopment, revised edition, ed. S. Fainstein, N. Fainstein, R. Hill, D. Judd, and M. Smith, 80-125. White Plains, NY: Longman.

Imbroscio, D. 1998. The necessity of urban regime change: A reply to Clarence N. Stone. Journal of Urban Affairs 20: 261-268.

. 2003. Overcoming the neglect of economics in urban regime theory. Journal of Urban Affairs 25: 271-284.

- 2010. Urban America reconsidered: Alternatives for governance and policy. Ithaca, NY: Cornell University Press.

Jonas, A. 1992. Corporate takeover and the politics of community: The case of Norton Company in Worcester. Economic Geography 68: 348-372.

Lauria, M., ed. 1997. Reconstructing urban regime theory: Regulating urban politics in a global economy. Thousand Oaks: Sage.

Logan, J., and H. Molotch. 1987. Urban fortunes: The political economy of place. Berkeley, CA: University of California Press.

Love, S., and D. Giffels. 1999. Wheels of fortune: The story of rubber in Akron. Akron, OH: University of Akron Press.

Martin, D. 2004. Nonprofit foundations and grassroots organizing: Reshaping urban governance. Professional Geographer 56: 394-405. 


\section{NETWORK RESTRUCTURING IN AKRON, 1975-2009}

Meyer, H. 2000. Boards take on heavy lifting. Journal of Business Strategy 21: 18-23.

Mills, C.W. 1956. The power elite. New York: Oxford University Press.

Mintz, B., and M. Schwartz. 1985. The power structure of American business. Chicago, IL: University of Chicago Press.

Mizruchi, M. 1992. The structure of corporate political action: Interfirm relations and their consequences. Cambridge, MA: Harvard University Press.

Oliver, R. 2000. The board's role: Driver's seat or rubber stamp? Journal of Business Strategy 21: 7-9.

Orr, M.E., and G. Stoker. 1994. Urban regimes and leadership in Detroit. Urban Affairs Review 30: $48-73$.

Powell, C. 2007. Akron biomedical drive gets results: Company expects to start making synthetic bones here next week. Akron Beacon Journal, March 8. (Accessed via Lexus Nexis, 20 July 2009).

Ratcliffe, R. 1980. Declining cities and declining capitalist class structure. In Power structure research, ed. G. Domhoff, 115-138. In New York: Sage.

Salzman, H., and G. Domhoff. 1980. The corporate community and government: Do they interlock? In Power structure research, ed. G. Domhoff, 227-254. In New York: Sage.

. 1983. Nonprofit organizations and the corporate community. Social Science History 7: 205-216.

Scott, A.J. 2001. Globalization and the rise of city-regions. European Planning Studies 9: 813-826.

Smith, J. 2010. "Re-stating" theories of urban development: The politics of authority creation and intergovernmental triads in postindustrial Chicago. Journal of Urban Affairs 32: 425-448.

Stone, C. 1989. Regime politics: Governing Atlanta, 1946-1988. Lawrence, KS: University of Kansas Press.

1993. Urban regimes and the capacity to govern: A political economy approach. Journal of Urban Affairs 15: 1-28.

2001. The Atlanta experience re-examined: The link between agenda and regime change. International Journal of Urban and Regional Research 21: 20-34.

_ 2005. Looking back to look forward: Reflections on urban regime analysis. Urban Affairs Review 40: 309-341.

2006. Power, reform and urban regime analysis. City and Community 5: 23-38.

Storper, M., and A.J. Venables. 2004. Buzz: Face-to-face contact and the urban economy. Journal of Economic Geography 4: 351-370.

Strom, E. 2002. Converting pork into porcelain: Cultural institutions and downtown development. Urban Affairs Review 38: 3-21.

Tretter, E. 2008. Scales, regimes, and the urban governance of Glasgow. Journal of Urban Affairs 30: $87-102$.

US States News. 2006. Mayor Plusquellic proposes biomedical corridor. 19 July. (Accessed via Lexus Nexis, 20 July 2009).

2007a. New life for historic East Market building, biomedical corridor to benefit. 08 January. (Accessed via Lexus Nexis, 20 July 2009).

2007b. Akron hospitals in joint venture: Summa, Akron General to have minority stakes in new acute-care facility. 24 January. (Accessed via Lexus Nexis, 20 July 2009).

Useem, M. 1984. The inner circle: Large corporations and the rise of business political activity in the U.S. and U.K. New York: Oxford University Press. 
Wall Street Journal. 2009. Sales and share of total market by manufacturer. 1 July 2009. http:// online.wsj.com/mdc/public/page/2_3022-autosales.html\#autosalesE (accessed 19 July 2009).

Ward, K. 1996. Rereading urban regime theory: A sympathetic critique. Geoforum 27: 427-438.

Wasserman, S., and K. Faust. 1994. Social network analysis: Methods and applications. Cambridge: Cambridge University Press.

Wood, A.M. 2004. Domesticating urban theory? US concepts, British cities and the limits of cross-national applications. Urban Studies 41: 2103-2118.

Wood, A. 2005. Comparative urban politics and the question of scale. Space and Polity 9: 201215.

Young, G., Y. Stedham, and R. Beekun. 2000. Boards of directors and the adoption of a CEO performance evaluation process: Agency-and institutional-Theory perspectives. Journal of Management Studies 37: 277-295.

Zacharias, C. 2000. New rules, new responsibilities. Journal of Accountancy 190: 53-55. 